\title{
Effects of the length of inundation periods on investment in tuber biomass and sexual reproduction by Vallisneria spinulosa S.Z. Yan Ramets
}

\author{
A.D. Fox ${ }^{(1)}$, F. Meng(2),(3), J. Liu'(2), W. Yang(2), K. Shan ${ }^{(2)}$, L. Cao(2),(3),
}

Received January 10, 2014

Revised March 14, 2014

Accepted March 18, 2014

\section{ABSTRACT}

Key-words:

China, submerged plant reproduction, Three Gorges Dam, vegetative reproduction, Yangtze River

Modification and reductions in flows are reducing inundation times in some Yangtze River wetlands, potentially affecting the growth of submerged macrophytes. The effects of shortening the inundation period from April to October (control) to April to September (treatment) were tested on the production of surface and below-ground tubers and fruits in individual Vallisneria spinulosa ramets in microcosm experiments. Mean numbers of below-ground tubers produced did not differ significantly between treatments, but individual tuber dry mass was significantly greater when harvested in October compared with plants harvested in September. Significantly more surface tubers were initiated by the ramets in the later harvest, but these did not differ in dry mass. Fewer ramets had initiated sexual reproduction by the September harvest compared with the October harvest. Almost all October fruits were mature, while the ratio of mature to unripe fruits was significantly greater than in September. There was no support for the hypothesis that more tubers were initiated deeper in the substrate with a longer inundation period to avoid predation by fish or birds. Based on these results, shortening of the inundation periods experienced by Vallisneria spinulosa plants in Yangtze River ephemeral wetlands may reduce the dry biomass of below-ground tubers and the production of surface tubers in this keystone macrophyte.

\section{RÉSUMÉ}

Effets de la durée de la période d'inondation sur l'investissement dans la biomasse des tubercules et la reproduction sexuée chez les ramets de Vallisneria spinulosa S.Z. Yan

Mots-clés :

Chine, reproduction plantes submergées, Barrage des Trois Gorges,
La modification et la réduction des débits réduisent les temps d'inondation dans certaines zones humides du fleuve Yangtsé, affectant potentiellement la croissance des macrophytes submergés. Les effets de la réduction de la durée de l'inondation d'avril à octobre (contrôle) à avril à septembre (traitement) ont été testés sur la production de tubercules de surface et souterrains et les fruits dans les différents ramets de Vallisneria spinulosa par des expériences en microcosmes. Le nombre moyen de tubercules souterrains produits ne diffère pas significativement entre les traitements, mais la masse sèche de tubercule était

(1) Department of Bioscience, Aarhus University, Kalø, Grenåvej 14, DK-8410 Rønde, Denmark

(2) School of Life Sciences, University of Science and Technology of China, 96 Jinzhai Road, Hefei, Anhui 230026,

P.R. China

(3) Present address: Department of Environmental Bio-Technology, Research Center for Eco-Environmental Sciences, Chinese Academy of Sciences, 18 Shuangqing Road, Haidian District, P.O. Box 2871, Beijing 100085, P.R.

^ Corresponding author: leicao@rcees.ac.cn 
reproduction végétative, Yangtsé significativement plus élevée lors de la récolte en octobre par rapport aux plantes récoltées en septembre. Significativement plus de tubercules de surface étaient formés par les ramets lors de la récolte tardive, mais ceux-ci ne diffèrent pas en masse sèche. Peu de ramets avaient entamé une reproduction sexuée lors de la récolte de septembre par rapport à celle d'octobre. Presque tous les fruits en octobre étaient matures et la proportion des fruits mûrs était significativement plus élevée qu'en septembre. Rien ne confirme l'hypothèse que plus de tubercules ont été formés plus profondément dans le substrat avec une longue période d'inondation pour éviter la prédation par les poissons ou les oiseaux. Sur la base de ces résultats, le raccourcissement des périodes d'inondation rencontrées par les plantes Vallisneria spinulosa dans les zones humides temporaires de la rivière Yangtsé peut réduire la biomasse sèche des tubercules souterrains et la production de tubercules de surface chez ce macrophyte clé.

\section{INTRODUCTION}

Globally, wetlands face continued loss and degradation (Findlayson and Davidson, 1999; Keddy et al., 2009), not least through pollution, eutrophication and water quality issues (Scheffer et al., 1993; Søndergaard et al., 2007). In addition, it is estimated that half of all wetlands face hydrological challenges, especially as a result of water regulation and abstraction, which interfere with flows and disrupt annual cycles of flood and desiccation, particularly as a result of dam construction (Keddy, 2010). Disruption of inundation regimes can affect growth and morphology (Zhang et al., 2013), impact submerged plant communities (Cronk and Fennessy, 2001) and ultimately have profound effects on biological communities and productivity (e.g. Stefanidis and Papastergiadou, 2013), and biodiversity and ecosystem services (Vörösmarty et al., 2010).

The ephemeral wetlands of the Yangtze River floodplain impose a seasonal cycle of inundation and desiccation to which water plants must adapt if they are to survive. This annual rhythm creates a temporally defined "reproductive" habitat when the wetland basins are filled with river flood waters in summer, interspersed with periods of complete desiccation when plants must resort to concealing propagules in "survival" habitats. During the inundation period, plants must construct the necessary photosynthetic architecture to initially provide maintenance metabolism, but ultimately to create a surplus for investment in survival during the desiccation period that inevitably follows. The survival strategies employed can be many and varied, but essentially involve plant investment in vegetative propagules and/or the fruits of sexual reproduction, either to survive in situ or through dispersal (Warwick and Brock, 2003). One of the keystone submerged macrophytes species of the Yangtze river floodplain, Vallisneria spinulosa S.Z. Yan, adopts three different survival strategies, investing in: (i) abovesubstrate tubers from rhizomes that penetrate above the soil surface, providing a means of waterborne dispersal; (ii) more numerous below-ground tubers that can survive in situ; and (iii) sexual reproduction to produce seeds that also offer a mechanism for larger-scale dispersal and gene flow. The ability of the plant to differentially invest in these survival mechanisms requires trade-offs with other metabolic pressures and constraints on the plant. One obvious limitation to the ability of the plant to maximize investment in all three survival mechanisms is the length of the inundation period and therefore the active growing period.

The basins of the Yangtze River floodplain experience relatively predictable annual cycles of winter water table drawdown and summer recharge, although water levels may vary greatly from year to year (Yang et al., 2007). Although precipitation and runoff have changed little in the Yangtze River catchment since the 1950s (Xu et al., 2010), reductions of flows in the Yangtze River, as a result of the Three Gorges Dam (TGD) and other changes to the hydrodynamics of the system, have shortened the inundation periods of middle-reach lakes (Seto et al., 2008; Zhang et al., 2011). Lower summer flood levels have been linked to advancement in the desiccation dates of basins such as Shengjin Lake (Zhang et al., 2011), so a foreshortening of the growth season of Vallisneria reflects current hydrological patterns and their likely 
exacerbation by climate change (Xu et al., 2010). It is therefore important to understand the effects of a shorter inundation period on the ability of the species to invest in asexual and sexual reproduction.

There is current concern about the reduction in diversity and biomass of submerged macrophytes in the Yangtze River floodplain (Fang et al., 2006). Widespread reductions in fish species richness, population size and fishery yields in many lakes have been blamed on declining water quality and flows (Fang et al., 2006; Cheng et al., 2009), but also on loss of submerged macrophyte beds, especially those of Vallisneria spp., which are highly prized and widely planted by fishermen (Fang et al., 2006; Cheng et al., 2009). Fish diversity and abundance are higher in submerged water plant beds compared with other habitats (Xie et al., 2000; Cheng et al., 2009), so planting of species such as Vallisneria has become important for lake restoration projects (Qiu et al., 2001). Recent studies show a collapse of the tuberforming $V$. spinulosa beds in Shengjin Lake in the Yangtze River floodplain, which represent the food base for a guild of migratory waterbirds that have decreased dramatically in abundance as a consequence (Fox et al., 2011). Since Vallisneria loss is suspected at other lakes within the system, affecting economic interests as well as biodiversity (e.g. Fang et al., 2006; Zhang et al., 2011), it is important to understand the factors contributing to the declines in submerged macrophytes.

In an earlier analysis, we demonstrated that shortening of the inundation period of the mainly sexually reproducing $V$. natans reduced annual biomass production and investment in viable seed (where the species exhibited no asexual propagation) (Cao et al., 2011). Vallisneria spinulosa is a keystone plant because of its contribution to ecosystem functions, including as a nursery habitat for fish species and as a food supply to large numbers of migratory waterbirds, so here we pose the question: is the tendency for shortening of the growth season likely to affect the ability of $V$. spinulosa to produce surface and below-ground tubers and reproduce sexually? Since it is not possible to answer this question in a field experiment, we address this question using a microcosm experiment. We manipulated growth season length in these microcosms to test if reductions in the growth period will reduce investment in above- and below-ground tuber biomass of individual $V$. spinulosa plants or the production of mature seeds. We also investigate a supplementary hypothesis that more tubers will be initiated at deeper depths in the substrate to avoid especially bird predation as the season progresses. Viability of Vallisneria tubers declines with burial depth (Rybicki and Carter, 1986), so deeper tuber burial carries a fitness price. However, a guild of migratory waterbird species excavate and consume $V$. spinulosa tubers buried in the top 15-20 cm of substrates during exposure by winter water level recession in Yangtze River wetlands (Fox et al., 2011), so mechanisms to avoid such predation bring survival benefits. Other submerged macrophytes show a flexible strategy to burial depth of their propagules as a herbivore avoidance strategy (e.g. Hidding et al., 2012).

\section{MATERIAL AND METHODS}

\section{> EXPERIMENTAL PROTOCOLS}

The microcosm study was conducted on a rooftop at the University of Science and Technology $\left(117^{\circ} 15^{\prime} 3.4^{\prime \prime} \mathrm{E} ; 31^{\circ} 50^{\prime} 26.9^{\prime \prime} \mathrm{N}\right)$, Hefei, under ambient climatic and light conditions. Substrates consisted of a mixture of two parts campus soil (a yellow-brown earth silt type) and one part standard potting compost from the Anhui Academy of Agricultural Sciences, mixed to evenness and used in all stages of all the experiments. Earlier studies have shown that $V$. spinulosa germinates and grows robustly in a range of substrates from gravels to silt (Ke and $\mathrm{Li}, 2006$ ). Water from the university supply (not chlorinated and left to stand for 2-3 days before use) was used in all experiments, which resulted in average nitrogen and phosphorus levels of $0.95( \pm 0.14595 \% \mathrm{Cl}) \mathrm{mg} \cdot \mathrm{L}^{-1}$ and $0.18( \pm 0.03995 \% \mathrm{Cl}) \mathrm{mg} \cdot \mathrm{L}^{-1}$ within the microcosms. TN and TP were determined using the potassium persulphate oxidation method, employing a 721-type spectrophotometer measuring at $200-210 \mathrm{~nm}$ and $700 \mathrm{~nm}$ wavelengths 
(Jin and Tu, 1996). Vallisneria species in lakes along the Yangtze River grow in waters of varying TN (0.05-9.00 mg. $\left.\mathrm{L}^{-1}\right)$ and TP (0.004-1.000 mg. $\mathrm{L}^{-1}$ ) (Xiong and Li, 2000; Xu and Jiang, 2009), and can purify eutrophicated water effectively with the removal rate of TP and TN being $>60 \%$ (Zhao et al., 2010).

Vallisneria tubers commence vigorous growth when the temperature is above $20^{\circ} \mathrm{C}(\mathrm{Li}$ and Cui, 2000), which occurs from late April in Hefei (http://www.tutiempo.net/en/Climate/Hefei. $\mathrm{htm})$. Due to the effects of TGD and other factors affecting river flows, the flood recession shows a shortening of one month at the end of the season. For this reason, we mimicked in vivo conditions in the microcosms, by creating two different inundation periods, a control one corresponding to normal Yangtze River patterns of inundation (1 April-30 October 2010) and a shortened treatment regime (1 April-30 September 2010) more typical of recent years.

\section{> SOURCE OF TUBERS AND INITIAL CULTIVATION}

Tubers, produced during experimental work in 2009, were kept outside over winter in 5-cmdeep damp soil in plastic boxes (46 cm $\times 35 \mathrm{~cm}$ by $26.5 \mathrm{~cm}$ deep). By 1 April 2010, the tubers broke dormancy and were producing green shoots, visible above the soil surface, as the temperature and daylight length increased. After this date, the water depth, initially kept at $5 \mathrm{~cm}$, was gradually increased to cover the plants as they grew in height.

\section{$>$ REPLANTING}

On 8 May, when the longest leaves began to float on the water surface, 44 plants of similar height and leaf state were selected (the mean height of all 108 plants was calculated and the 44 plants whose height was nearest to the mean value were chosen). Two of these were selected for each container, replanted symmetrically in $5-\mathrm{cm}$ holes in each of 22 large $80-\mathrm{cm}$-high containers (internal diameters: top $61 \mathrm{~cm}$; bottom $50 \mathrm{~cm}$ ). The 22 containers were randomly arranged in an open roof area. Soil depth was set at $30 \mathrm{~cm}$, greater than the maximum tuber depth found in the field (Fox et al., 2011) and, after replanting, water depth was immediately increased to, and maintained at, $50 \mathrm{~cm}$ (the maximum obtainable).

\section{> DAILY OBSERVATIONS}

Plants were checked daily, and timing of florescence and production of mature fruits was recorded. Phytoplankton was removed by net and periphyton carefully removed by hand from the containers to ensure plant growth was unaffected. From 28 July, mature and unripe fruits that had separated from the plants and were floating on the water surface were collected, counted and weighed every 10 days.

\section{> HARVESTING}

Half of the microcosms were randomly selected for harvest on 30 September and the remainder on 30 October. Containers were drained and the whole leaves, surface tubers and fruits in each container were collected, washed and divided into leaves and surface tubers (above-ground biomass), mature fruits (seeds brown or black) and unripe fruits (seeds green or yellow), before drying at $60{ }^{\circ} \mathrm{C}$ for $48 \mathrm{~h}$ and weighed.

$V$. spinulosa is dioecious, although the sex of plants could not be determined at the transplanting stage. As a result, only three containers in the September sample contained female plants and only two of these had produced mature fruits by the first harvest. Amongst the containers harvested later, eight contained female plants, of which all had produced mature fruits by October. 
For each harvesting period, leaves and fruits were collected and removed on the harvest date, but because of the time taken to locate and extract the below-ground tubers, these were removed later. The below-ground tubers in each container were excavated and collected as quickly as possible during the following 1-30 days. Using the soil surface as the datum for measuring tuber depths in soil, mud was carefully removed progressively and the depth of the first shoot of each tuber measured to the nearest $1 \mathrm{~mm}$. Tubers were numbered consecutively, removed, gently cleaned with a toothbrush, the length measured, placed in separate paper bags, dried at $60{ }^{\circ} \mathrm{C}$ for $48 \mathrm{~h}$ and weighed. In September, 10 out of 11 containers were harvested (one leaking container was rejected), whilst 5 out of 11 containers were harvested in October (these were thought to adequately reflect the distribution and abundance of belowground tubers in the longer growing period).

\section{> DATA ANALYSIS}

Data from the two growing periods were analysed separately. Mean dry weight values of leaf biomass, surface and below-ground tubers, and mature fruits were calculated per container. Tubers were separated into five depth classes in the substrate according to their original distribution (0-1.0 cm (defined as surface tubers), 1.1-5.0 cm; $5.1-10.0 \mathrm{~cm} ; 10.1-15.0 \mathrm{~cm}$; and $15.1-20.0 \mathrm{~cm}$ ), to facilitate the analysis of depth distribution. We tested for differences in the numbers of surface and below-ground tubers per plant between September and October harvests using one-way ANOVA. Differences in total tuber biomass, mean tuber biomass, number of fruits, number of ripe fruits and biomass of ripe fruits produced per container between September and October were tested using one-way ANOVA. Differences in tuber numbers and mean tuber biomass between different depths and harvest dates were tested using two-way ANOVA and group means were compared using Duncan's Multiple Range tests $($ alpha $=0.05$ ). All statistical analyses were carried out using SPSS 16.0 (IBM Corporation, Somers, NY 10589).

\section{RESULTS}

\section{>ABOVE-GROUND BIOMASS}

The total combined leaf lengths of plants assigned to September and October harvests were not significantly different in May (Table I). Above-ground green biomass showed more signs of senescence in the later harvest compared with plants harvested in September, with the result that the mean above-ground biomass was significantly less in October (Table I).

\section{> PRODUCTION OF SURFACE TUBERS}

Plants in containers harvested in September had significantly less surface tubers than those harvested in October (Table I). This represented an increase from 1.2\% to $4.9 \%$ in the proportion of surface tubers per container of the total (i.e. surface plus below-ground tubers). The mean dry biomass of the surface tubers per container did not significantly differ between harvests (Table I).

\section{> PRODUCTION OF BELOW-GROUND TUBERS}

There were no significant differences between the numbers of below-ground tubers produced per container between September and October harvests (Table I, Figure 1). The mean dry biomass production of below-ground tubers per container was significantly greater in the October harvest than the September harvest (Table I, Figure 2), the result of a significant increase in the mean dry biomass of individual tubers between treatments (Table I, Figure 2). 
Table I

Mean ( $\pm 95 \%$ confidence intervals) measurements of numbers of tubers and mature fruits and their dry biomass of Vallisneria spinulosa in relation to harvest time. Comparisons of treatments are based on ANOVA and Duncan's Multiple Range tests with the threshold alpha $<0.05$.

\begin{tabular}{|c|c|c|c|c|}
\hline \multirow[b]{2}{*}{ Items } & \multicolumn{2}{|c|}{ Mean $\pm 95 \%$ CI } & \multirow[b]{2}{*}{ ANOVA F value } & \multirow[b]{2}{*}{$P$} \\
\hline & $\begin{array}{c}\text { September } \\
\text { harvest group }\end{array}$ & $\begin{array}{c}\text { October } \\
\text { harvest group }\end{array}$ & & \\
\hline $\begin{array}{l}\text { The initial total combined } \\
\text { leaf lengths }(\mathrm{cm})\end{array}$ & $492.2 \mathrm{~cm} \pm 221.2$ & $326.2 \mathrm{~cm} \pm 132.3$ & $F_{1,9}=1.73$ & 0.22 \\
\hline Above-ground biomass (g) & $31.0 \mathrm{~g} \pm 4.72$ & $23.0 \mathrm{~g} \pm 4.14$ & $F_{1,20}=6.37$ & 0.02 \\
\hline Number of surface tubers & $3.9 \pm 1.858$ & $19.4 \pm 5.460$ & $F_{1,13}=44.10$ & $<0.001$ \\
\hline Dry biomass of surface tubers (g) & $0.127 \mathrm{~g} \pm 0.027$ & $0.105 \mathrm{~g} \pm 0.021$ & $F_{1,135}=1.36$ & 0.25 \\
\hline Number of below-ground tubers & $204.8 \pm 27.022$ & $223.8 \pm 31.685$ & $F_{1,13}=0.70$ & 0.42 \\
\hline $\begin{array}{l}\begin{array}{l}\text { Mean dry biomass of below-ground } \\
\text { tubers on container level }(\mathrm{g})\end{array} \\
\end{array}$ & $0.190 \mathrm{~g} \pm 0.015$ & $0.235 \mathrm{~g} \pm 0.023$ & $F_{1,13}=11.20$ & 0.005 \\
\hline $\begin{array}{l}\begin{array}{l}\text { Mean dry biomass of below-ground } \\
\text { tuber on individual tuber level(g) }\end{array} \\
\end{array}$ & $0.187 \mathrm{~g} \pm 0.005$ & $0.232 \mathrm{~g} \pm 0.008$ & $F_{1,3164}=102.90$ & $\ll 0.001$ \\
\hline $\begin{array}{l}\text { Mean dry weight of tubers at } \\
\text { successive layers on container } \\
\text { level (g) }\end{array}$ & & & $F_{7,59}=30.18$ & $<0.001$ \\
\hline $\begin{array}{l}\text { Mean dry weight of tubers at } \\
\text { successive layers on individual } \\
\text { tuber level(g) }\end{array}$ & & & $F_{7,3146}=52.4$ & $<0.001$ \\
\hline $\begin{array}{l}\text { Mean number of mature fruits } \\
\text { produced per container }\end{array}$ & $32 \pm 17.4$ & $15 \pm 22.9$ & $F_{1,10}=1.13$ & 0.31 \\
\hline $\begin{array}{l}\text { Mean dry biomass of mature fruits } \\
\text { produced per container }(\mathrm{g})\end{array}$ & $1.137 \mathrm{~g} \pm 1.076$ & $0.448 \mathrm{~g} \pm 0.870$ & $F_{1,10}=0.52$ & 0.49 \\
\hline The proportion of mature fruits & $0.934 \pm 0.065$ & $0.222 \pm 0.408$ & $F_{1,10}=30.98$ & $<0.001$ \\
\hline
\end{tabular}

\section{> DISTRIBUTION OF TUBERS WITHIN THE SUBSTRATE}

Overall, there was no change in the distribution of below-ground tubers between the two successive harvests, but below-ground tuber dry mass increased between harvests at all soil levels. There were significant differences in the distribution of tubers at successive layers down through the soil (Table I), but there were no significant differences in the numbers at different levels between the two harvest dates based on Duncan's Multiple Range tests (Figure 1). Tuber abundance peaked between 10.1 and $15 \mathrm{~cm}$ below the surface, but fell rapidly beyond this depth; only 3 out of 3249 tubers occurred below $20 \mathrm{~cm}$. There were significant differences in the mean dry weight of tubers at increasing depths (Table I), including significant differences in the mean dry biomass at different levels between the two treatments based on Duncan's Multiple Range tests (Figure 2).

\section{> PRODUCTION OF MATURE FRUITS}

The mean number of mature fruits produced per container did not differ significantly between harvests (Table I). The mean dry biomass of mature fruits produced per container in October was more than double that in September, but these did not differ significantly because of the small sample size and high variance in both samples (Table I). The proportion of mature fruits was significantly greater in October than in September (Table I).

\section{DISCUSSION}

The microcosm experiments showed that replicated $V$. spinulosa ramets initiating growth in April produced significantly more surface tubers (although of similar individual dry biomass) 


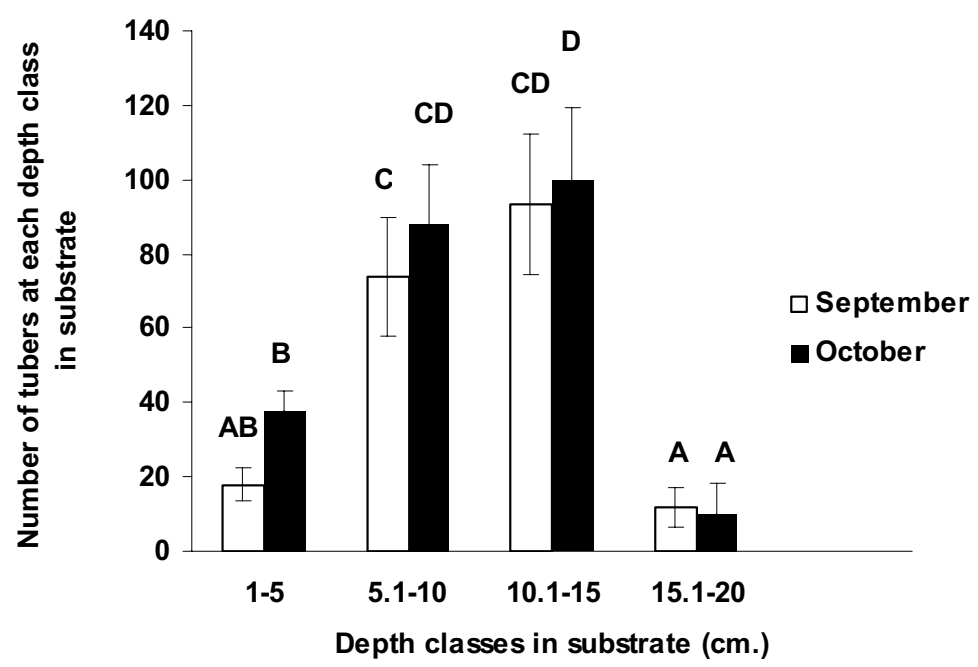

\section{Figure 1}

Mean ( $\pm 95 \%$ confidence intervals) numbers of Vallisneria spinulosa tubers accumulated at successive layers at increasing soil depths in each container by harvest time. Treatments with the same letter signify no significant difference between these treatments; means based on ANOVA and Duncan's Multiple Range tests with the threshold alpha $<0.05$.

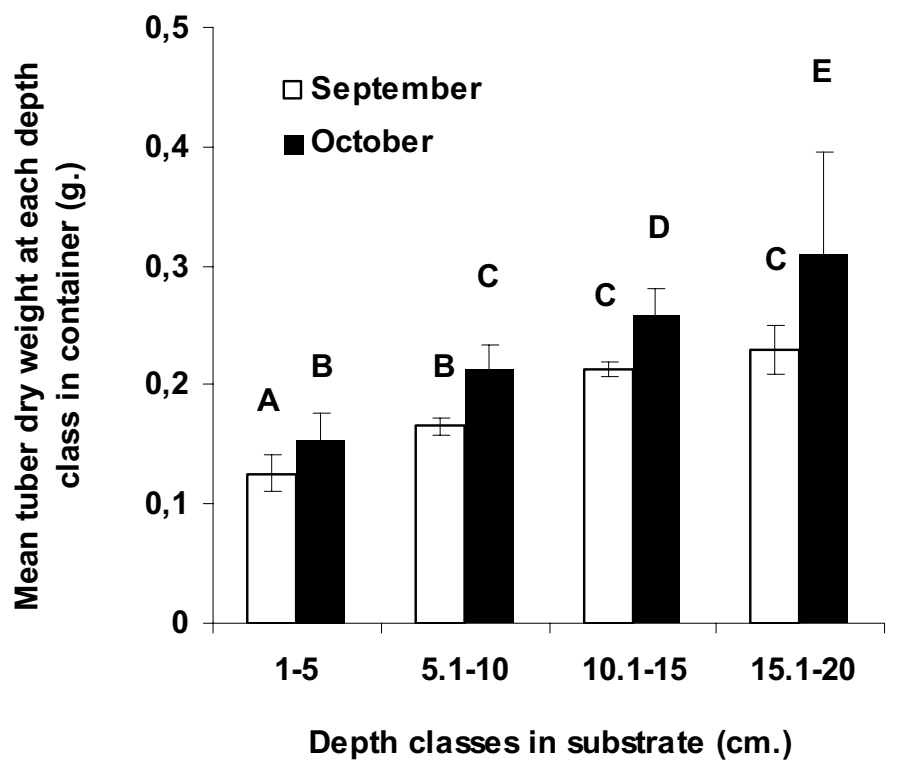

\section{Figure 2}

Mean ( $\pm 95 \%$ confidence intervals) dry biomass of Vallisneria spinulosa tubers accumulated at successive layers at increasing soil depths in each container by the time of the harvest. Treatments with the same letter signify no significant difference between these treatments; means based on ANOVA and Duncan's Multiple Range tests tests with the threshold alpha $<0.05$.

if allowed to grow until October compared with September. The increase in surface tubers suggested a late end-of-season investment in dispersal by this means. In contrast, the number of below-ground tubers did not differ between the September and October harvests, although the individual dry biomass of these increased significantly between harvests. It is likely, but not confirmed, that greater biomass investment in tubers in this species may contribute to elevated survival probability (as demonstrated for Potamogeton pectinatus tubers, Spencer, 1987; Santamaria and Rodriguez-Girones, 2002) and will be correlated with 
improved above-ground production in the subsequent year (as demonstrated for P. pectinatus tubers, Hangelbroek and Santamaría, 2004). We suspect that under normal circumstances, $V$. spinulosa reproduces mainly clonally, regrowing from tubers that survive winter desiccation and which are rewetted by inundation every following summer season (Yan and Zhu, 1984), so the quality of tubers produced in a given year may affect the fitness of an individual. Under natural conditions, it is known that the tubers in the substrate suffer heavy predation from waterbirds (Fox et al., 2011); however, although the number of surface tubers significantly increased, there was no indication from the microcosm experiments that tuber distribution within the substrate changed as the season progressed (see Santamaria and Rodriguez-Girones, 2002).

Because of the problems associated with culturing dioecious plants, not all containers had male/female combinations, with the result that sample sizes relating to sexual reproductive investment were limited. Thus, although few plants had initiated sexual reproduction and succeeded in producing mature fruits by the September harvest, and the October plants on average produced seven times the dry biomass of all fruits per ramet, the differences failed to reach statistical significance. Nevertheless, almost all the fruits present in October were mature, and the ratio of mature to unripe fruits increased significantly between the two harvests, suggesting greater potential success in sexual reproduction by the latter date. Seeds are often emphasised as estimates of plant fitness, but clonal growth also affects genet fitness through genet persistence and seed reproduction (Pan and Price, 2004). Asexual reproduction predominates over sexual in many if not most aquatic angiosperms, and plants with tubers are associated with highly productive stable habitats where neighbours (inter- and intra-specific competitors) are large (Grace, 1993). Although essentially a clonal species, flowering and production of viable seeds can be abundant in $V$. spinulosa and sexually-derived seedling recruitment is thought by many authors to contribute strongly to population persistence in lakes in the middle-lower reaches of the Yangtze River (Xiong, 2000; Chen et al. 2007). If this is the case, clearly reduction in flowering, maturing of fruits and production of viable seed caused by reductions in the inundation period will further contribute to reductions in fitness in this species.

In other Vallisneria species, such as $V$. natans and $V$. australis, seed viability is high over a range of environmental conditions and represents a means of survival when vegetative survival is low due to prolonged desiccation or salinity (Choudhuri, 1996; Ke and Li, 2006; Salter et al., 2008, 2010). For V. spinulosa investment in sexual reproduction may therefore be vital under circumstances of unpredictable environmental conditions for long-distance dispersal, while the species relies more heavily on local dispersal of asexual clones through tuber survival (Santamaria, 2002). The restricted sample size gave equivocal results on the degree of investment in sexual reproduction because of our inability to predict the sex of plants, as measured by the dry weight of mature fruit production, but the indications are that investment in sexual reproduction could be affected by shortening the growth season, as found in $V$. natans (Thompson, 1992). The results of these two experiments together suggest that reductions in the period of inundation in a largely annual species ( $V$. natans) reduce investment in sexual reproduction and in a perennial species ( $V$. spinulosa) in over-wintering tuber mass, implying that especially earlier desiccation of the Yangtze River wetlands in autumn could affect recruitment of both species of submerged macrophyte, despite their differing reproduction strategies. Nevertheless, we need to undertake further experimental studies to establish whether such differences in reproductive investment in propagules (either seeds or tubers) have any substantial effect on the subsequent survival and growth of plants that grow from them. This is especially important because changes in viability of below- ground tubers would probably contribute to declines in population over shorter time scales than amongst those in seed and surface tubers. These results demonstrate how the effects of river regulation and water abstraction can shorten the periods of inundation for submergent plants without affecting the above-ground green biomass, yet have potential impacts on the investment in sexual and asexual reproduction that have broader significance outside of the Yangtze River floodplain. 


\section{ACKNOWLEDGEMENTS}

The study was supported the National Natural Science Foundation of China (Grant No. 31370416). We are enormously grateful to Mark Barter, the journal editor and two anonymous referees for their help in preparing and improving the manuscript, and laboratory staff for assisting with sorting plants.

\section{REFERENCES}

Cao L., Meng F., Yang W., Shan K., Liu J. and Fox A.D., 2011. Effects of length of growing season on biomass accumulation and reproductive investment of Vallisneria natans (Lour.) $\mathrm{H}$. Hara. Fund. Appl. Limnol., 179, 115-120.

Chen L., Xu L. and Huang H., 2007. Genetic diversity and population structure in Vallisneria spinulosa (Hydrocharitaceae). Aquat. Bot., 86, 46-52.

Cheng D., Xiong F., Wang K. and Chang Y., 2009. Status of research on Yangtze fish biology and fisheries. Environ. Biol. Fish., 85, 337-357.

Choudhuri G.N., 1966. Seed germination and flowering in Vallisneria spiralis. Northwest Sci., 40, 31-35.

Cronk J.K. and Fennessy M.S., 2001. Wetland Plants: Biology and Ecology. CRC Press/Lewis Publishers, Boca Raton, FL.

Fang J., Wang Z., Zhao S., Li Y., Tang Z., Yu D., Ni L., Liu H., Xie P., Da L., Li Z. and Zheng C., 2006. Biodiversity changes in the lakes of the Central Yangtze. Front. Ecol. Environ., 4, 369-377.

Finlayson C.M. and Davidson N.C., 1999. Global Review of Wetland Resources and Priorities for Wetland Inventory. Ramsar Convention Bureau, Gland (Switzerland).

Fox A.D., Cao L., Zhang Y., Barter M., Zhao M.J., Meng F.J. and Wang S.L., 2011. Declines in the tuber-feeding waterbird guild at Shengjin Lake National Nature Reserve, China - a barometer of submerged macrophyte collapse. Aquat. Conserv., 21, 82-91.

Grace J.B., 1993. The adaptive significance of clonal reproduction in angiosperms: an aquatic perspective. Aquat. Bot. 44, 159-180.

Hangelbroek H.H. and Santamaría L., 2004. Regulation of propagule size in the aquatic pseudo-annual Potamogeton pectinatus: are genetic and maternal non-genetic effects additive? Evol. Ecol. Res., $6,147-161$.

Hidding B., Klaassen M., de Boer T., de Vries P.P. and Nolet B.A., 2012. Aquatic plant shows flexible avoidance by escape from tuber predation by swans. Basic Appl. Ecol., 13, 50-58.

Jin X.C. and Tu Q.Y., 1996. Specifications for Lake Eutrophication (2nd edition). China Env Sci Press, Beijing, pp. 162-164 (in Chinese).

Ke X. and Li, W., 2006. Germination requirement of Vallisneria natans seeds: implications for restoration in Chinese lakes. Hydrobiologia, 559, 357-362.

Keddy P.A., 2010. Wetland Ecology: Principles and Conservation (2nd edition). Cambridge University Press, Cambridge, pp. 46-74.

Keddy P.A., Fraser L.H., Solomeshch A.I., Junk W.J., Campbell D.R., Arroyo M.T.K. and Alho C.J.R., 2009. Wet and wonderful: the world's largest wetlands are conservation priorities. BioScience 59, 39-51.

Li Y.D. and Cui Y.Q., 2000. Germination experiment on seeds and stem tubers of Vallisneria natans in Lake Donghu of Wuhan. Acta Hydrobiol. Sin., 24, 298-300.

Pan J.J. and Price J.S., 2002. Fitness and evolution in clonal plants: the impact of clonal growth. Evol. Ecol. 15, 583-600.

Qiu D., Wu Z.B., Liu B.Y., Deng J.Q., Fu G.P. and He F., 2001. The restoration of aquatic macrophytes for improving water quality in a hypertrophic shallow lake in Hubei Province, China. Ecol. Eng., 18, 147-156.

Rybicki N.B., and Carter V., 1986. Effects of sediment depth and sediment type on the survival of Vallisneria americana Michx. grown from tubers. Aquat. Bot. 24, 233-240.

Salter J., Morris K. and Boon P.I., 2008. Does salinity reduce the tolerance of two contrasting wetland plants, the submerged monocot Vallisneria australis and the woody shrub Melaleuca ericifolia, to wetting and drying? Mar. Freshwater Res., 59, 291-303. 
Salter J., Morris K., Read J. and Boon P.I., 2010. Effect of drying, salinity and temperature on seed germination of the submersed wetland monocot, Vallisneria australis. Fund. Appl. Limnol., 177, 105-114.

Santamaría L., 2002. Why are most aquatic plants widely distributed? Dispersal, clonal growth and small-scale heterogeneity in a stressful environment. Acta Oecolog. 23, 137-154.

Santamaria L. and Rodriguez-Girones M.A., 2002. Hiding from swans: optimal burial depth of sago pondweed tubers foraged by Bewick's swans. J. Ecol., 90, 303-315.

Scheffer M., Hosper S.H., Meijer M.L., Moss B. and Jeppesen E., 1993. Alternative equilibria in shallow lakes. Trends Ecol. Evol., 8, 275-279.

Seto E.Y.W., Wu W., Liu H.Y., Chen H.G., Hubbard A., Holt A. and Davis G.M., 2008. Impact of changing water levels and weather on Oncomelania hupensis hupensis populations, the snail host of Schistosoma japonicum, downstream of the Three Gorges Dam. Ecohealth, 5, 149-158.

Søndergaard M., Jeppsesen E., Lauridsen T.L., Skov C., Van Nes E. H., Roijackers R., Lammens E. and Portielje R., 2007. Lake restoration: successes, failures and long-term effects. J. Appl. Ecol., 44, $1095-1105$.

Spencer D.F., 1987. Tuber size and planting depth influence growth of Potamogeton pectinatus L. Am. Midl. Nat., 118, 77-84.

Stefanidis K. and E. Papastergiadou E., 2013. Effects of a long term water level reduction on the ecology and water quality in an eastern Mediterranean lake. Knowl. Manag. Aquat. Ecosyst., 411, 05.

Thompson K., 1992. The functional ecology of seed banks. In: Fenner, M. (ed.): Seeds, the ecology of regeneration in plant communities. CAB International, Wallingford, 231-258.

Vörösmarty C.J., McIntyre P.B., Gessner M.O., Dudgeon D., Prusevich A., Green P., Glidden S., Bunn S.E., Sullivan C.A., Reidy Liermann C., and Davies P.M., 2010. Global threats to human water security and river biodiversity. Nature, 467, 555-561.

Warwick N.W.M. and Brock M.A., 2003. Plant reproduction in temporary wetlands: the effects of seasonal timing, depth, and duration of flooding. Aquat. Bot., 77, 153-167.

Xie S., Cui Y., Zhang T., Fang R. and Li Z., 2000. The spatial pattern of the small fish community in the Biandantang Lake - a small shallow lake along the middle reaches of the Yangtze River, China. Environ. Biol. Fish., 57, 179-190.

Xiong, B.H., 2000. Ecological Studies on Vallisneria L. in Poyang Lake, Jiang Xi. Masters Thesis. Wuhan Institute of Botany, the Chinese Academy of Sciences (in Chinese, with English abstract).

Xiong B.H. and Li W., 2000. Ecology studies on Vallisneria L. in China. J. Wuhan Bot. Res., 18, 500-508 (In Chinese).

Xu K., Milliman J.D., Yang Z. and Wang H., 2006. Yangtze sediment decline partly from Three Gorges Dam. Eos Trans. AGU, 87, 185-196.

Xu Z.X. and Jiang Y.P., 2009. Lake eutrophication assessment: comprehensive water quality identification index. J. Tongji Uni. (Nat. Sci.), 37, 1044-1048 (in Chinese).

Yan S.Z. and Zhu W.J., 1984. Comparative morphological studies on three species of Vallisneria from China. Guihaia, 4, 309-315 (in Chinese, with English abstract).

Yang S.L., Zhang J. and Xu X.J., 2007. Influence of the Three Gorges Dam on downstream delivery of sediment and its environmental implications, Yangtze River. Geophys. Res. Let., 34, L10401.

Zhang X., Liu X. and Ding Q., 2013. Morphological responses to water-level fluctuations of two submerged macrophytes, Myriophyllum spicatum and Hydrilla verticillata. J. Plant Ecol. 6, 64-70.

Zhang Y., Cao L., Fox A.D., Zhao M.J., Meng F.J., Shi H.Q., Jiang Y. and Zhu, W.Z., 2011. Changing distribution and abundance of Swan Geese Anser cygnoides in the Yangtze River floodplain: the likely loss of a very important wintering site. Bird Conserv. Int., 21, 36-48.

Zhao D., Xu W.J., Li Y. and Chen H., 2010. Purification of eutrophicated water by Vallisneria spinulosa. Chinese Agr. Sci. Bull., 26, 189-192 (in Chinese). 